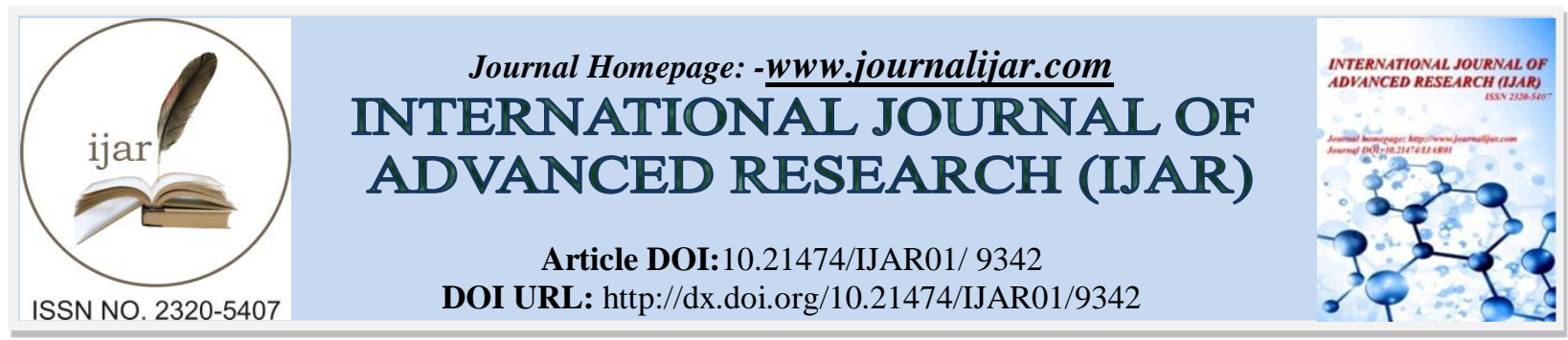

RESEARCH ARTICLE

\title{
EVALUATION ON IMPLEMENTATION OF ELECTRONIC RECIPES (E-RECIPES) IN Dr. WAHIDIN SUDIROHUSODO HOSPITAL, MAKASSAR.
}

Juwita $^{1}$, Fridawaty Rivai ${ }^{2}$ and Ansariadi ${ }^{3}$.

1. Departement of Hospital Administration Management, Faculty of Public Health, Hasanuddin University.

2. Departement of Epidemiology, Faculty of Public Health, Hasanuddin University.

\section{Manuscript Info}

Manuscript History

Received: 04 May 2019

Final Accepted: 06 June 2019

Published: July 2019

Key words:-

Electronic Recipe (E-Recipe), Implementation, Communication, Resources, Disposition, Bureaucratic Structure.

\begin{abstract}
This study aims to determine the implementation of the E-Recipe and develop a strategy for improving the implementation of E-Recipes at Dr. RSUP. Wahidin Sudirohusodo Makassar.

This research is qualitative research using quantitative data and qualitative data. Quantitative data obtained from the data of EPrescription Implementation and qualitative data obtained from the results of observations and interviews with informants.

The results of this study indicate that from the quantitative data of ERecipe implementation during May 2019 in Dr. Wahidin Sudirohusodo General Hospital Makassar is $11.41 \%$ and from the qualitative data the results of observations and interviews with informants indicate that communication has been given to implementers through education and socialization but not yet to all service rooms, human resources as implementers are sufficient but in terms of computer facilities that are not sufficient to implement E-Recipes and also applications that support the implementation of E-Recipe must be developed, implementer compliance is still very low because they still consider many procedures the manual prescription sheet must be done and still available, from also already available Standard Operating Procedure (SPO) and in terms of coordination and cooperation between installations it has been running well. The strategy prepared is to reconvene the meeting, educate education related to the implementation of the E-Recipe policy, make direct visits to all rooms, develop the application of Electronic Drug Control (E-KPO), Electronic Medical Record (E-KPO), Clinical Decision Support System, and connections to clinical support results, conducting education on the use of computer replacement cellphones, conducting direct monitoring throughout the room, removing manual prescription sheets.
\end{abstract}

Copy Right, IJAR, 2019,. All rights reserved.

\section{Introduction:-}

The occurrence of medication errors (medication errors) is an indication of the level of achievement of patient safety, especially towards the goal of achieving safe medication. According to the National Hospital Accreditation

Corresponding Author:-Juwita.

Address:-Departement of Hospital Administration Management, Faculty of Public Health, 
Standard (SNARS) the occurrence of medication errors can be divided into three criteria, namely the phase of prescribing error, phase dispensing error and administration error phase (error giving) (RI Ministry of Health, 2017).

Whereas in order to improve the quality of health services, comprehensive and responsive actions are needed for unintended events in health care facilities so that similar incidents do not recur (Ministry of Health, 2017)

Electronic prescriptions play a role in decreasing prescribing errors mainly due to the writing process, while to reduce errors due to doctor's decision need to add support systems and clinical pharmacy interventions to improve medication safety. The perception of the benefits of the electronic prescribing system has more influence on the use of electronic prescribing systems than perceptions of convenience. The incompleteness of prescription writing is significantly higher in non-electronic prescriptions than electronic prescriptions. Writing is not meaningfully read only in non-electronic prescriptions on 91 recipes. The risk of drug interactions and other errors in the form of inappropriate drug selection, polypharmacy and unusual dosages does not diminish with electronic prescriptions. Other factors that influence the prescribing error are the doctor's professional background, the age of the patient, the concoction and the number of types of drugs in the recipe. More than $50 \%$ of doctors agree and strongly agree on the perception of ease and perception of the benefits of electronic prescriptions (Susi Widiastuti et al., 2014).

\section{Theoretical Framework}

Recipe

Recipe is a written request from a doctor or dentist, to a pharmacist, both in paper and electronic form to provide and submit drugs to patients according to applicable regulations (Ministry of Health, 2016)

\section{Electronic Recipes (E-Recipes)}

E-Prescribing or Electronic Recipe (E-Recipe) is a prescribing system using software designed to facilitate prescribing services starting from prescribing, transcribing (recipe reading for dispensing), dispensing stages (preparation up to prescription submission by officers), administration stage (drug use process) and monitoring process (Hahn \& Lovett, 2014).

\section{Implementation theory}

According to the theory of implementation by Edward III (Winarno, 2008) that an implementation will be influenced by several factors which include: Communication, Resources, Disposition and Structure of the Bureaucracy.

\section{Materials And Methods:-}

\section{Location and Design of Research}

This research was conducted at Dr. RSUP Wahidin Sudirohusodo Makassar. The type of research used is qualitative analytic using qualitative study design

\section{Method of collecting data}

Data collection is done by observation, document study, in-depth interviews with parties related to the implementation of E-Recipe and FGD to develop strategies for improving the implementation of E-Recipe

\section{Informant}

This research was conducted by conducting in-depth interviews with structural and functional staff and Specialist Medical Education Students (MPPDS).

\section{Data analysis}

Data analysis was carried out with a qualitative study approach using quantitative data and qualitative data, namely organizing data, reading and making memos and describing, classifying and interpreting data so as to explain in more depth the implementation of E-recipes and the factors that influence implementation as well as in RSUP Dr . Wahidin Sudirohusodo Makassar. 


\section{Results:-}

Quantitative data

Table 1:-Implementation of Prescription Services in RSUP Dr.Wahidin Sudirohusodo Makassar May of 2019

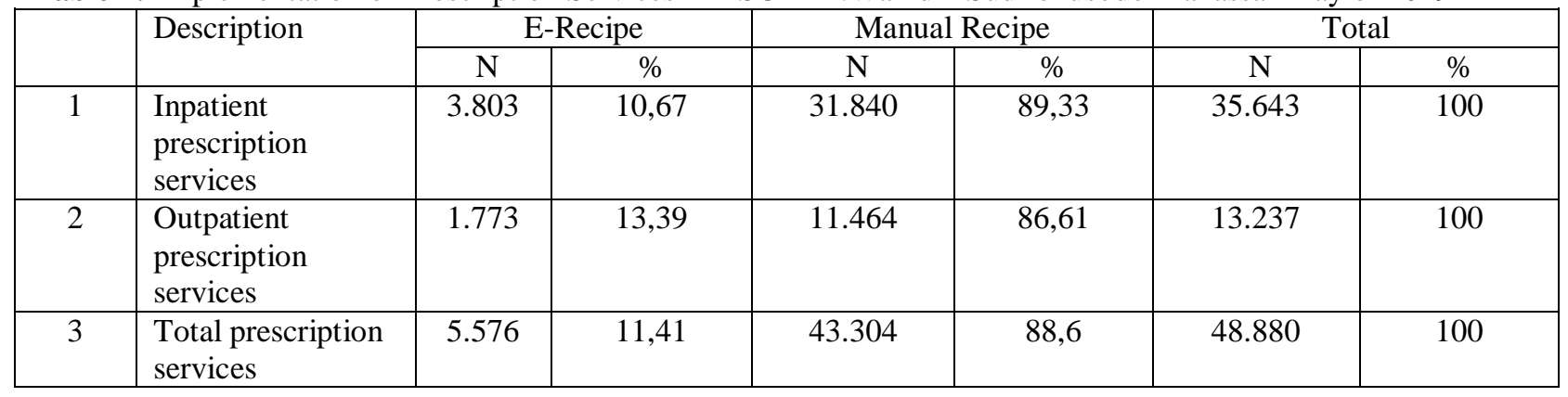

The table shows that the number of E-Recipes during May 2019 was $11.41 \%$.

Qualitative Data

Table 2 :-Strategies for Improving the Implementation of E-Recipes in RSUP Dr. Wahidin Sudirohusodo Makassar in May 2019

\begin{tabular}{|c|c|c|c|}
\hline & Research Results & Strategy for Improving Implementation & Person in charge \\
\hline 1. & $\begin{array}{l}\text { Implementation of } \\
\text { E-Recipe } 11.41 \%\end{array}$ & $\begin{array}{l}\text { Conduct coordination, resocialisation and } \\
\text { education meetings related to the } \\
\text { implementation of E-Prescription policies }\end{array}$ & Medical and Nursing Directors \\
\hline 2. & $\begin{array}{l}\text { Direct assistance is } \\
\text { not comprehensive. }\end{array}$ & Direct assistance to all rooms & Head of SIRS Installation \\
\hline 3. & $\begin{array}{l}\text { The application is } \\
\text { incomplete and } \\
\text { integrated }\end{array}$ & $\begin{array}{l}\text { Performing application development (E- } \\
\text { KPO), E-Medical Record (E-MR), DCSS, } \\
\text { and Connection to the results of supporting }\end{array}$ & $\begin{array}{l}\text { Head of Medical and Nursing } \\
\text { Division }\end{array}$ \\
\hline 4. & $\begin{array}{l}\text { Lack of Computer } \\
\text { facilities }\end{array}$ & Educating the use of the Cellular Telephone & Head of SIRS Installation \\
\hline 5. & $\begin{array}{l}\text { Compliance and } \\
\text { commitment Doctors } \\
\text { are still low. }\end{array}$ & $\begin{array}{l}\text { Monitor the implementation directly in the } \\
\text { Installation }\end{array}$ & Head of Installation \\
\hline 6. & $\begin{array}{l}\text { Use of the manual } \\
\text { prescription sheet } \\
88.41 \%\end{array}$ & Eliminate of manual prescription sheet & Head of Support Services \\
\hline
\end{tabular}

The Table shows the results of compiling strategies for improving the implementation of E-Recipes.

In-depth interviews were conducted with 9 informants who had structural and functional positions as well as students from the Specialist Medical Education Program (MPPDS).

These results indicate that communication has been given in accordance with the results of interviews with informants who said that "Education and socialization has been provided to implementers through education and outreach but not to all rooms of service"

Human resources as implementers are sufficient but in terms of computer facilities it is not sufficient to implement E-Recipes and also applications that support the implementation of E-Recipes must be developed, according to the results of interviews with informants who stated that "Doctors are sufficient but computer facilities are still lacking and the E-Recipe support system application must be developed ".

Compliance with implementers is still very low because they still consider many procedures to be done and still available manual prescription sheets, according to the results of interviews with informants who said that "E-Recipe implementation is still low because doctors are still using manual prescription sheets". 
Operational Procedure Standard (SPO) is already available and in terms of coordination and cooperation between installations has been running well in accordance with the results of interviews with informants stating that "coordination has been carried out between units / installations namely pharmaceutical installations, SIRS installations and nurses"

\section{Discussion:-}

The results of the study showed that the implementation of the E-Recipe at Dr. RSUP Wahidin Sudirohusodo Makassar is still very low at $11.4 \%$, this can be caused by the fact that there is still a manual prescription sheet which according to the informant that it is easier to use, from the results of a CPOE implementation study that there are three top success factors assessed by survey respondents are: "training before starting", adequate clinical resources during implementation, and order time (Altuwaijri et al., 2011).

Policy communication in the form of meetings, outreach, and direct assistance has been carried out, but direct assistance has not been comprehensive so it is necessary to conduct resocialization and assistance directly to the field throughout the room and the Functional Medical Unit (SMF) according to research on the adoption of Computerized Phisician Order Entry (CPOE) shows the three obstacles that are most often identified are: process changes $(23 \%)$, training $(13 \%)$, and benefits $(10 \%)$. If successfully implemented, the CPOE system can improve the treatment process, quality of care, and patient outcomes and meaningful use (Kruse \& Goetz, 2015).

Human Resources (HR) are sufficient and have the authority to implement E-Recipe, but in terms of computer facilities according to interviews with several informants must be completed but according to other informants can use the E-Recipe application on Cellular Phones (Cellphones) because all rooms are equipped with WIFI networks, in terms of applications must be developed applications related to E-Recipes such as Electronic Drug Control (EKPO), Electronic Medical Records (E-RM) and Clinical Decision Support Systems as well as connections with supporting results for example laboratory results according to research who said that a total of 594 elements were obstacles or facilitators for the implementation of e-prescription. Most user groups assume that e-prescriptioning is facilitated by design and technical problems, interoperability, content that is appropriate for users, attitudes toward available e-prescription, productivity, and resources (Gagnon et al., 2014).

Commitment and compliance are still low, based on the results of interviews from several informants who say that compliance and commitment depend on the characteristics of each implementer while from other informants say that the implementer will commit but not all have E-Recipe applications and according to other informants the E-Recipe application requires there are many procedures that require a long time according to the study which says that various weaknesses require attention (Hellström et al., 2009)

Operational Procedure Standard (SPO) is already available to become a standard in the field and cooperation between units / installations has been carried out in the framework of implementing the E-Recipe. According to research that says that a proper understanding of CPOE as a collaborative effort and the transformation of health care activities into integrated care programs requires an understanding of how orders are made and processed, how CPOE as part of an integrated system can support workflows, and how risks can affect patient care identified and reduced, especially during hand-offs in workflows (Aarts, Ash, \& Berg, 2007)

\section{Conclusions And Recommendations:-}

The results of the implementation of E-Recipe are still low at $11.41 \%$ and the strategy prepared is to re-convene the meeting, educate education regarding the implementation of the E-Prescription policy, make a direct visit to all rooms, develop the Electronic Drug Control application (E-KPO), Electronic Medical Record (E-KPO), Clinical Decision Support System, and connection to clinical support results, conduct education on the use of computer replacement cell phones, conduct monitoring directly in all rooms, eliminate manual prescription sheets. 


\section{References:-}

1. Aarts, J., Ash, J., \& Berg, M. (2007). Extending the understanding of computerized physician order entry: Implications for professional collaboration, workflow and quality of care. International Journal of Medical Informatics. https://doi.org/10.1016/j.ijmedinf.2006.05.009

2. Altuwaijri, M., Bahanshal, A., \& Almehaid, M. (2011). Implementation of computerized physician order entry in National Guard hospitals: Assessment of critical success factors. Journal of Family and Community Medicine, 18(3), 143. https://doi.org/10.4103/2230-8229.90014

3. Gagnon, M. P., Nsangou, É. R., Payne-Gagnon, J., Grenier, S., \& Sicotte, C. (2014). Barriers and facilitators to implementing electronic prescription: A systematic review of user groups' perceptions. Journal of the American Medical Informatics Association. https://doi.org/10.1136/amiajnl-2013-002203

4. Hahn, A., \& Lovett, A. (2014). Electronic Prescribing: An Examination of Cost Effectiveness, Clinician Adoption and Limitations. Universal Journal of Clinical Medicine, 2(1), 1-24. https://doi.org/10.13189/ujcm.2014.020101

5. Hellström, L., Waern, K., Montelius, E., Strand, B., Rydberg, T., \& Petersson, G. (2009). Physicians attitudes towards ePrescribing -evaluation of a swedish full-scale implementation. BMC Medical Informatics and Decision Making, 9(1), 1-10. https://doi.org/10.1186/1472-6947-9-37

6. Kementerian Kesehatan RI. (2016). Permenkes 72 tahun 2016 Tentang Standar Pelayanan Kefarmasian.

7. Kementerian Kesehatan RI. (2017). Permenkes RI No 112017 Tentang Keselamatan Pasien. (308).

8. Kruse, C. S., \& Goetz, K. (2015). Summary and Frequency of Barriers to Adoption of CPOE in the U.S. Journal of Medical Systems, 39(2). https://doi.org/10.1007/s10916-015-0198-2

9. Susi Widiastuti, M., Iwan Dwiprahasto, D., Pelayanan Medis Swasta, B. R., Farmakologi Klinis dan Terapi, B., Kedokteran, F., Gadjah Mada, U., \& Penelitian, A. (2014). Peran Resep Elektronik Dalam Meningkatkan Medication Safety pada Proses Peresepan. In $30 \square$ Jurnal Manajemen Pelayanan Kesehatan (Vol. 17).

10. Winarno, B. (2008). Kebijakan Publik : Teori dan Proses. Jakarta: PT. Buku Kita. 